\title{
STOSOWANIE LEKÓW PRZECIWBÓLOWYCH W RÓŻNYCH GRUPACH WIEKOWYCH Z UWZGLĘDNIENIEM RELACJI MIĘDZYPOKOLENIOWYCH
}

\section{USING ANALGESICS IN DIFFERENT AGE GROUPS, INCLUDING INTERGENERATIONAL RELATIONS}

\author{
Marcin Weiner $^{1(\mathrm{~A}, \mathrm{C}, \mathrm{D}, \mathrm{E}, \mathrm{F})}$, Małgorzata Tokarska-Rodak ${ }^{1(\mathrm{~A}, \mathrm{C}, \mathrm{D}, \mathrm{E}, \mathrm{F})}$, Anna Bida ${ }^{1(\mathrm{~B}, \mathrm{C}, \mathrm{D}, \mathrm{F})}$ \\ ${ }^{1}$ Państwowa Szkoła Wyższa im. Papieża Jana Pawła II w Białej Podlaskiej
}

\begin{abstract}
Weiner, M., Tokarska-Rodak, M., Bida, A. (2019). Stosowanie leków przeciwbólowych w różnych grupach wiekowych z uwzględnieniem relacji międzypokoleniowych. Rozprawy Społeczne, 13(1), 72-79. https://doi.org/10.29316/rs.2019.09
\end{abstract}

Wkład autorów:

A. Zaplanowanie badań

B. Zebranie danych

C. Dane - analiza i statystyki

D. Interpretacja danych

E. Przygotowanie artykułu

F. Wyszukiwanie i analiza

literatury

G. Zebranie funduszy

\begin{abstract}
Streszczenie
Wprowadzenie. Pomimo obostrzeń związanych z sprzedaża produktów leczniczych na przestrzeni 8 lat wzrosła blisko 2-krotnie sprzedaż apteczna leków dostępnych bez recepty (Over -The-Counter drug, OTC). Wpływ na to ma szeroki dostepp do farmaceutyków, zaniechania w zasięgnięciu profesjonalnej porady lekarskiej i zbyt długie kolejki do lekarza pierwszego kontaktu. Cel pracy. Celem pracy było zbadanie zależności w przyjmowaniu leków przeciwbólowych dostępnych bez recepty pomiędzy trzema grupami wiekowymi: studentami (pokolenie I), ich rodzicami (pokolenie II) i dziadkami (pokolenie III).

Materiał i metoda. Grupę badawczą stanowiły 203 osoby (150 kobiet i 53 mężczyzn) w wieku od 19 do 92 lat (śr. wieku: 48 lat, SD: 22,18). W badaniu posłużono się metodą sondażu diagnostycznego opartego na autorskim kwestionariuszu ankietowym, w których pytano o stan zdrowia oraz preferencje przyjmowanych preparatów.

Wyniki. Najczęściej wybieraną substancją czynną przeciwbólowych leków OTC jest ibuprofenum (116 osób - 65,91\%). Na drugim miejscu znajduje się paracetamolum, który wybiera 95 badanych $(53,98 \%)$. Acidum acetylosalicylicum stosuje 58 osób (32,95\%). Mniej popularne sa substancje takie jak sól sodowa metamizolu, diclofenak i naproxenum. Deklarację przyjmowania przeciwbólowych leków OTC „na własną rękę” składa 176 na 203 ankietowanych (86,70\%), 61 osób $(85,92 \%)$ w pokoleniu I, 64 osoby $(90,14 \%)$ w pokoleniu II oraz 51 osób $(83,61 \%)$ w pokoleniu III.

Wnioski. Częstość stosowania leków przeciwbólowych różni się pomiędzy analizowanymi grupami respondentów należących do trzech różnych pokoleń. Osoby starsze częściej $(15 \%)$ niż osoby młode $(1,4 \%)$ sięgają po leki przeciwbólowe kilka razy dziennie. Natomiast zdecydowanie wyższy odsetek osób młodego pokolenia $(75,7 \%)$ stosuje tego typu preparaty sporadycznie.
\end{abstract}

Słowa kluczowe: leki przeciwbólowe, NLPZ, OTC, różnice międzypokoleniowe, samoleczenie

\section{Summary}

Objectives. In spite of the restrictions associated with the sale of medicinal products over the past 8 years, the over-the-counter drug sales have nearly doubled. This is caused by a broad access to pharmaceuticals, abandonment of professional medical advice, and too many long queues to the general practitioner.

The aim of the study was to investigate the dependence in the use of over-the-counter analgesics among three age groups: students (generation I), their parents (generation II) and grandparents (generation III).

Material and methods. The research group consisted of 203 persons ( 150 women and 53 men) between 19 and 92 years of age (mean age: 48 years, SD: 22.18). The study used a diagnostic questionnaire based on the author's questionnaire which asked the respondents about their health status and preferences in taking medicines.

Results. The most commonly prescribed active ingredient for pain relievers in OTC drugs is ibuprofen (116 people - 65.91\%). Then comes paracetamolum, which is chosen by 95 persons (53.98\%). Acidum acetylsalicylicum attracts 58 people $(32.95 \%)$. Less common are such substances as metamizol sodium, diclofenac and naproxenum. About 176 out of 203 respondents $(86.70 \%)$ declare taking OTC painkillers "on their own", 61 of them $(85.92 \%)$ in generation I, 64 $(90.14 \%)$ in generation II and $51(83.61 \%)$ in generation III.

Conclusions. The frequency of taking OTC painkillers in the members of particular generations of the family depends on their age. Older persons (15\%) more often take analgesics several times a day. Only $(1.4 \%)$ of the young do it. On the other hand, a considerably higher percentage of young people $(75.7 \%)$ use such medications sporadically.

Keywords: analgetic, NSAID, OTC, intrageneration differences, self-treatment
Ryciny: 6

Literatura: 12

Otrzymano: listopad 2017

Zaakceptowano: marzec 2018

Adres korespondencyjny: Maricn Weiner, Państwowa Szkoła Wyższa w Białej Podlaskiej, ul. Sidorska 95/97, 21-500 Biała Podlaska, e-mail: m.weiner@ dydaktyka.pswbp.pl, tel.: 833449900

ORCID: Marcin Weiner https://orcid.org/0000-0001-9288-0823; Małgorzata Tokarska-Rodak https://orcid.org/0000-0003-2297-970X

Copyright by: Państwowa Szkoła Wyższa im. Papieża Jana Pawła II w Białej Podlaskiej,Marcin Weiner, Małgorzata Tokarska-Rodak, Anna Bida 


\section{Wstęp}

Lekiem przeciwbólowym OTC (Over-The-Counter drug) nazywa się każdy preparat o działaniu przeciwbólowym, który ma niską dawkę terapeutyczną i jest wydawany bez przepisu lekarza (Ustawa z dnia 6 września 2001 o prawie farmaceutycznym). Najczęstszym podziałem leków przeciwbólowych dostępnych bez recepty jest klasyfikacja według substancji czynnej, a zarazem podział na dwie grupy: Niesteroidowych Leków Przeciwzapalnych (NLPZ) oraz leków z grupy analgetyków nieopioidowych. Światowa Organizacja Zdrowia opracowała drabinę analgetyczną składającą się z 3 stopni, która dzieli leki przeciwbólowe według stopnia nasilenia bólu (Eisenberg i in., 2005). Na 1 stopniu znajdują się NLPZ i paracetamol, czyli większość leków przeciwbólowych dostępnych bez recepty. Na kolejnym stopniu opioidy o słabszym działaniu (np. tramadol i kodeina), a na najwyższym szczeblu są leki opioidowe o silnym działaniu (np. morfina, fentanyl, metadon). Tylko leki z najniższego stopnia drabiny analgetycznej są dostępne bez recepty, a ich stosowanie nie jest w żaden sposób kontrolowane (Jarosz, Respondek, 2011).

Leki przeciwbólowe OTC z grupy NLPZ, czyli wszystkie te, które za substancję czynną mają ibuprofenum, acidum acetylsalicylicum, diclofenak, metamizolum lub naproxenum, działają na zasadzie hamowania syntezy prostaglandyn, które są regulatorami wszystkich procesów fizjologicznych człowieka i występują we wszystkich tkankach oraz płynach ustrojowych (Woroń, Filipczak-Bryniarska, Wordliczek, 2001). Dodatkowo poza działaniem przeciwbólowym, wykazują działanie przeciwzapalne, przeciwgorączkowe oraz antyagregacyjne wydłużając czas krzepnięcia krwi. Najsilniejszy z tej grupy leków metamizol wykazuje się także słabym działaniem spazmolitycznym. Natomiast acidum acetylsalicylicum, czyli popularna Etopiryna lub Polopiryna, nie pomaga w bólach trzewnych. Wszystkie leki z grupy NLPZ cechują się wysoką skutecznością uśmierzania dolegliwości bólowych, ale są także obarczone wysokim ryzykiem działań niepożądanych, interakcji z innymi lekami oraz ich powikłań (Rajtar-Cynke, 2012). Paracetamol, będący lekiem z drugiej grupy leków przeciwbólowych dostępnych bez recepty, hamuje aktywność cyklooksygenazy prostaglandynowej w Ośrodkowym Układzie Nerwowym (OUN), wpływa przeciwgorączkowo, ale nie wykazuje działania przeciwzapalnego oraz antyagregacyjnego. Jest lekiem bezpiecznym także dla dzieci, jego stężenie toksyczne jest 6-10 razy większe od stężenia terapeutycznego, stąd też ciężko o jego przedawkowanie. W połączeniu z NLPZ (np. Metafen - paracetamol + ibuprofenum) istotnie zwiększa działanie przeciwbólowe w uśmierzaniu bólów pooperacyjnych, pourazowych czy zwyrodnieniowych. Paracetamol, w przeciwieństwie do NLPZ, nie podrażnia błony śluzowej żołądka oraz nie uszkadza nerek. Nie ma też właściwości antyagregacyjnych, dlatego może być stosowany przez osoby leczące się lekami przeciwpłytkowymi (Woroń i in., 2001).

Leki przeciwbólowe $\mathrm{w}$ połączeniu $\mathrm{z}$ lekami przyjmowanymi na stałe mogą powodować groźne sytuacje, np. paracetamol nasila działanie doustnych leków przeciwzakrzepowych i może spowodować krwotok, a w połączeniu z NLPZ zwiększa ryzyko uszkodzenia wątroby. Metoklopramid - lek przeciwwymiotny, przyspiesza wchłanianie paracetamolu, a propantelina - lek stosowany w leczeniu nadreaktywności pęcherza, opóźnia wchłanianie paracetamolu. Metamizol, poza nasileniem leków przeciwzakrzepowych, zwiększa reakcję doustnych leków przeciwcukrzycowych, a w połączeniu z chlorpromazyną (stosowaną w leczeniu przeciwpsychotycznym) może wywoływać hipotermię. Kwas acetylosalicylowy zawarty w Aspirynie, Polopirynie S i Etopirynie działa synergicznie z innymi lekami przeciwzapalnymi, przeciwgorączkowymi oraz przeciwbólowymi, zwiększa działanie leków przeciwzakrzepowych i doustnych leków przeciwcukrzycowych, ale jednocześnie osłabia działanie furosemidu, inhibitorów ACE i $\beta$-adrenolityków leków stosowanych w nadciśnieniu tętniczym krwi (Rajtar-Cynke, 2012).

Nadmierne przyjmowanie NLPZ zaburza krzepnięcie krwi, utrudnia gojenie się ran, zwiększa ryzyko chorób układu pokarmowego, np. wzdęcia, nudności, wymioty, chorobę wrzodową (owrzodzenia żołądka i/lub dwunastnicy), krwawienia z układu pokarmowego. Ponadto uszkadza wątrobę, prowadzi do niewydolności nerek, zaburza równowagę kwasowo-zasadową, skutkuje odczynami skórnymi i reakcjami alergicznymi, może zaostrzać stany astmatyczne. Kwas acetylosalicylowy może negatywnie wpłynąć na płodności u mężczyzn, a metamizol uszkodzić szpik, przyczynić się do niedokrwistości hemolitycznej i odwarstwienia siatkówki. Nadmierne spożycie paracetamolu zaburza strukturę morfotyczną krwi (Woroń i in., 2001).

Niekorzystnym i niepokojącym zjawiskiem jest polipragmazja, czyli jednoczesne stosowanie wielu leków oraz niewłaściwa ich ordynacja. W głównej mierze dotyczy osób starszych, z kilkoma chorobami w wywiadzie medycznym, na które przyjmuje od kilku do kilkunastu leków w ciągu dnia. Polipragmazja i niepożądane działania leków to trzecia przyczyna hospitalizacji i zgonów, po nowotworach i chorobach układu krążenia. Przyczyną polipragmazji jest nie tylko samoleczenie pacjenta, ale również brak koordynacji działań medycznych pomiędzy lekarzami specjalistami w ustalaniu terapii uwzględniającej różne dolegliwości pacjenta i zażywane przez nich leki (Wykowski, 2016).

\section{Cel pracy}

Celem pracy było zbadanie zależności dotyczącej przyjmowania leków przeciwbólowych dostępnych bez recepty pomiędzy trzema grupami wiekowymi: studentami, ich rodzicami i dziadkami. 


\section{Materiał i metody}

W badaniu posłużono się metodą sondażu diagnostycznego opartego na autorskim kwestionariuszu ankietowym, w których pytano o stan zdrowia (samoocenę stanu zdrowia) oraz preferencje przyjmowanych preparatów przeciwbólowych. Ankietowanych zapytano o opinię na temat rodzaju, częstotliwości i przyczyn zażywanych substancji oraz miejsca zakupu. Badania prowadzono w okresie wrzesień - listopad 2015 roku. W związku z realizacją celu w zakresie analizy międzypokoleniowej ankiety rozdano studentom kierunków medycznych Państwowej Szkoły Wyższej im. Papieża Jana Pawła II w Białej Podlaskiej oraz osobom należącym do ich rodzin (rodzeństwo, rodzice, dziadkowie).

Grupę respondentów stanowiło 203 osoby (150 kobiet i 53 mężczyzn) w wieku od 19 do 92 lat (śr. wieku: 48 lat, SD: 22,18):

- w pokoleniu I - 71 osób młodych (54 kobiet i 17 mężczyzn), średnia wieku: 23 lata, SD: 4,36;

- w pokoleniu II - 71 osób w wieku średnim pokolenie rodziców (52 kobiet i 19 mężczyzn) średnia wieku: 50 lat, SD: 6,88;
- w pokoleniu III - 61 osób starszych - pokolenie dziadków (44 kobiety i 17 mężczyzn) średnia wieku: 76 lat, SD: 7,21.

Analizę statystyczną wykonano w programie STATISTICA. Obliczono strukturę odpowiedzi na poszczególne pytania dla trzech badanych pokoleń respondentów. W celu wykrycia istotnych statycznie różnic pomiędzy badanymi grupami zastosowano test Chi kwadrat Pearsona. We wszystkich analizowanych przypadkach, przyjęto poziom istotności $\mathrm{p}=0,05$.

\section{Wyniki}

\section{Deklarowany stan zdrowotny grupy badanej}

Analiza zadeklarowanych przez respondentów chorób zdiagnozowanych przez lekarza wykazała, że wraz z wiekiem badanych wzrasta chorobowość (z 25 chorób występujących w pokoleniu I do 139 w pokoleniu III). Najwięcej osób leczy się na nadciśnienie tętnicze (64 ogółu ankietowanych - 31,53\%) i towarzyszące temu choroby serca (46 osób - 22,66\%). Ponad 3/4 ludzi młodych (54 osoby

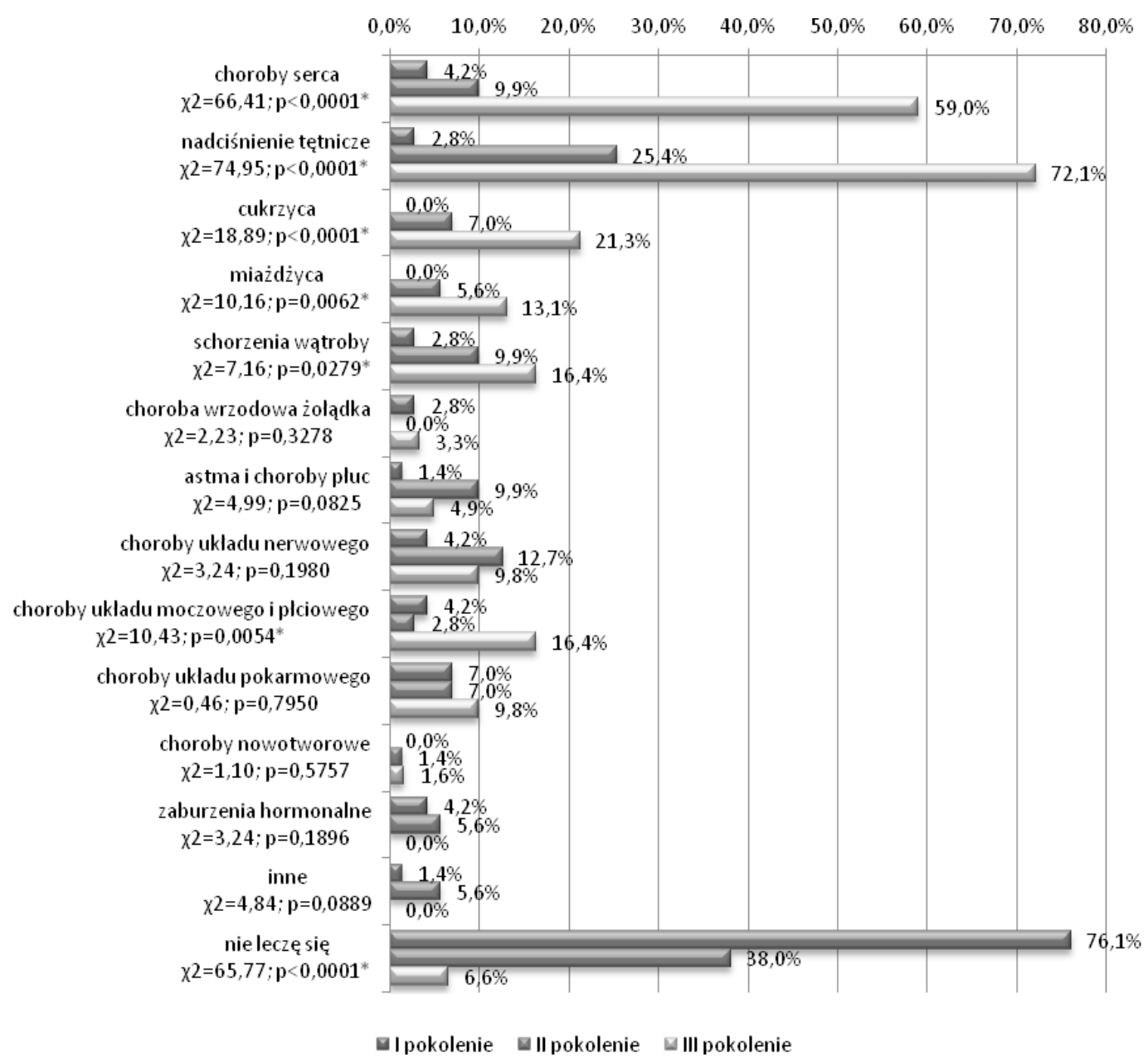

$\chi$ 2-wartość testu Chi kwadrat Pearsona; *-istotne zróżnicowanie dla $\mathrm{p}<0,05$

Rycina 1. Zdiagnozowane schorzenia w związku z którymi ankietowani stosują leczenie

Źródło: Opracowanie własne 
- 76,06\%) oraz 1/3 ich rodziców (27 osób - 38,03\%) nie ma żadnych zdiagnozowanych chorób i nie wymaga leczenia. Szczegółowe dane dotyczące chorób deklarowanych przez respondentów zawarto na rycinie 1.

Uzyskane wyniki wskazują, iż schorzenia takie jak cukrzyca, miażdżyca i choroby nowotworowe nie występują w najmłodszym pokoleniu. Pokolenie II nie zgłasza występowania choroby wrzodowej żołądka, a wśród osób pokolenia III nie ma zdiagnozowanych problemów hormonalnych.

\section{Deklarowane stosowanie leków przeciwbólo- wych dostępnych bez recepty lekarskiej}

Deklarację przyjmowania przeciwbólowych leków OTC „na własną rękę” składa 176 na 203 ankietowanych $(86,70 \%), 61$ osób $(85,92 \%)$ w pokoleniu I, 64 osoby $(90,14 \%)$ w pokoleniu II oraz 51 osób $(83,61 \%)$ w pokoleniu III.

Najczęściej wybieraną substancją czynną przeciwbólowych leków OTC jest ibuprofenum (116 osób - 65,91\%), dostępny pod takimi nazwami handlowymi jak: Ibuprom, Ibum, Ibufen, Nurofen. Na drugim miejscu znajduje się paracetamolum, składnik popularnego Apapu lub Panadolu, który wybiera 95 badanych $(53,98 \%)$. Acidum acetylsalicylicum, obecny w Aspirynie, Polopirynie S i Etopirynie, stosuje 58 osób (32,95\%). Mniej popularne są substancje takie jak sól sodowa metamizolu (składnik Pyralginy), diclofenak (Diclofenac) i naproxenum (Naproxen, Aleve). Szczegółowe wyniki uwzględniające odpowiedzi udzielone przez osoby należące do trzech pokoleń zamieszczono na rycinie 2 .
Powody sięgania po przeciwbólowe leki dostępne bez wcześniejszej wizyty u lekarza przedstawia rycina 3. Przeważająca większość respondentów (137 osób - 77,84\%) sięga po nie w bólach głowy i migrenach. Ponad 1/3 kobiet przyjmujących leki przeciwbólowe (47 z 135 - 34,81\%), w znacznej większości kobiet $\mathrm{z}$ najmłodszego pokolenia (35 z 49 - 71,43\%), przyjmuje leki przeciwbólowe w czasie menstruacji. Bóle reumatyczne łagodzi 54 z 176 osób (30,68\%), głównie z pokolenia III (33 z 51 przyjmujących leki przeciwbólowe - 64,71\%). Urazy sportowe stanowią konieczność do terapii przeciwbólowej "na własną rękę" dla 9 z 176 osób przyjmujących leki przeciwbólowe $(5,11 \%)$.

Deklarowana częstotliwość przyjmowania leków przeciwbólowych dostępnych bez recepty przedstawia rycina 4. Spośród respondentów 117 osób $(57,64 \%)$ sięga sporadycznie po środki uśmierzające ból, zaś 33 osoby $(16,26 \%)$ przyjmują leki przeciwbólowe OTC kilka razy w tygodniu, a blisko $7 \%$ badanych ankietowanych (13 osób) stosuje je kilka razy dziennie.

Przeważająca część respondentów dokonuje zakupu środków przeciwbólowych OTC w aptece 174 osób (91,1\%) z 191 osób kupujących. Z analizy danych wynika, że wzrasta znaczenie sklepów spożywczych jako docelowego punktu nabycia środków przeciwbólowych. Kiosk, stacja benzynowa, drogeria kosmetyczna i sklep zielarski są wybierane sporadycznie - odpowiednio przez 17 (8,9\%), 10 $(5,24 \%), 7(3,67 \%)$ i $6(3,14 \%)$ osób. Nikt spośród respondentów nie dokonuje zakupu leków przeciwbólowych w sklepie z odżywkami i suplementami. Szczegółowe dane zamieszczono na rycinie 5.

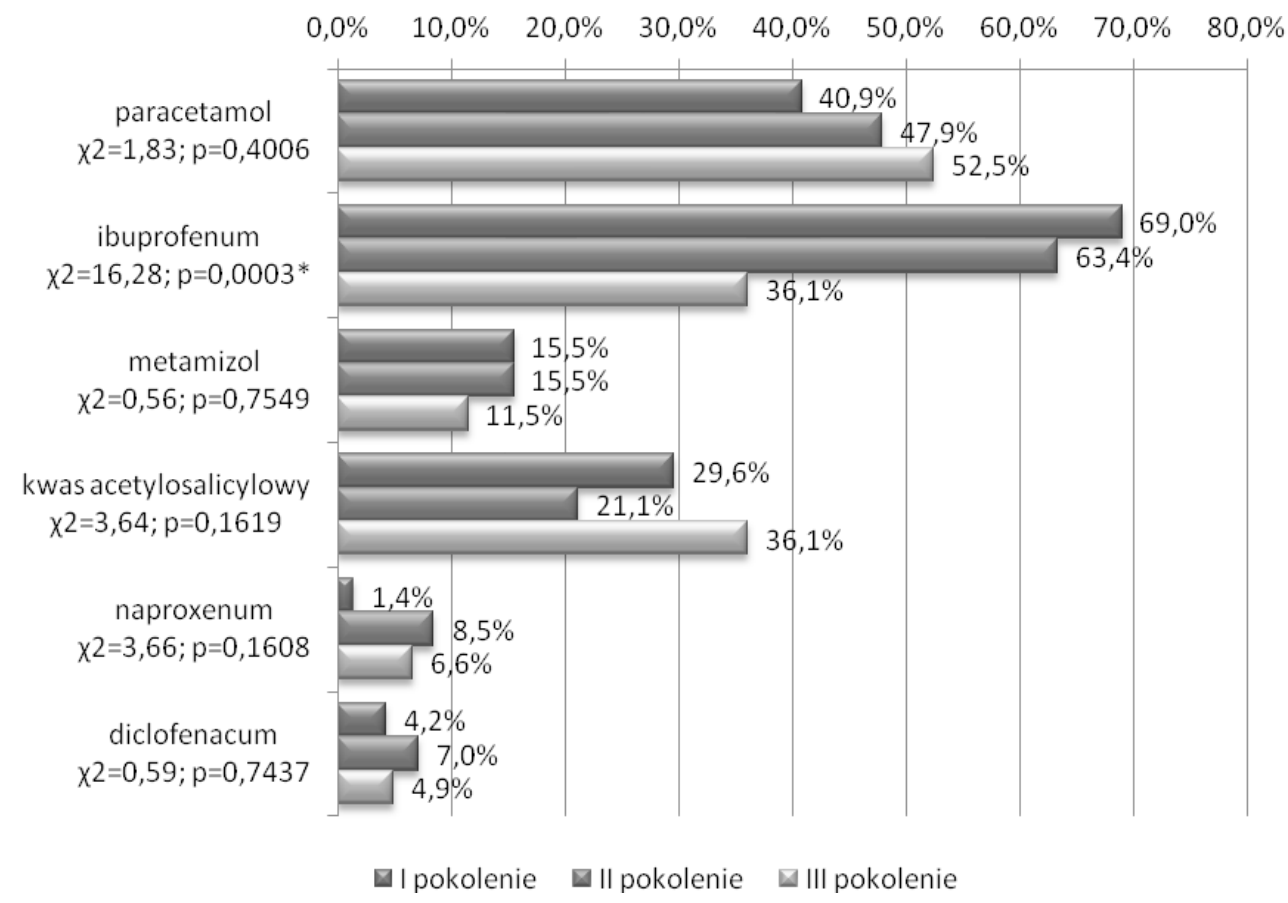

$\chi 2$-wartość testu Chi kwadrat Pearsona; *-istotne zróżnicowanie dla p<0,05

Rycina 2. Rodzaj stosowanych leków przeciwbólowych

Źródło: Opracowanie własne 


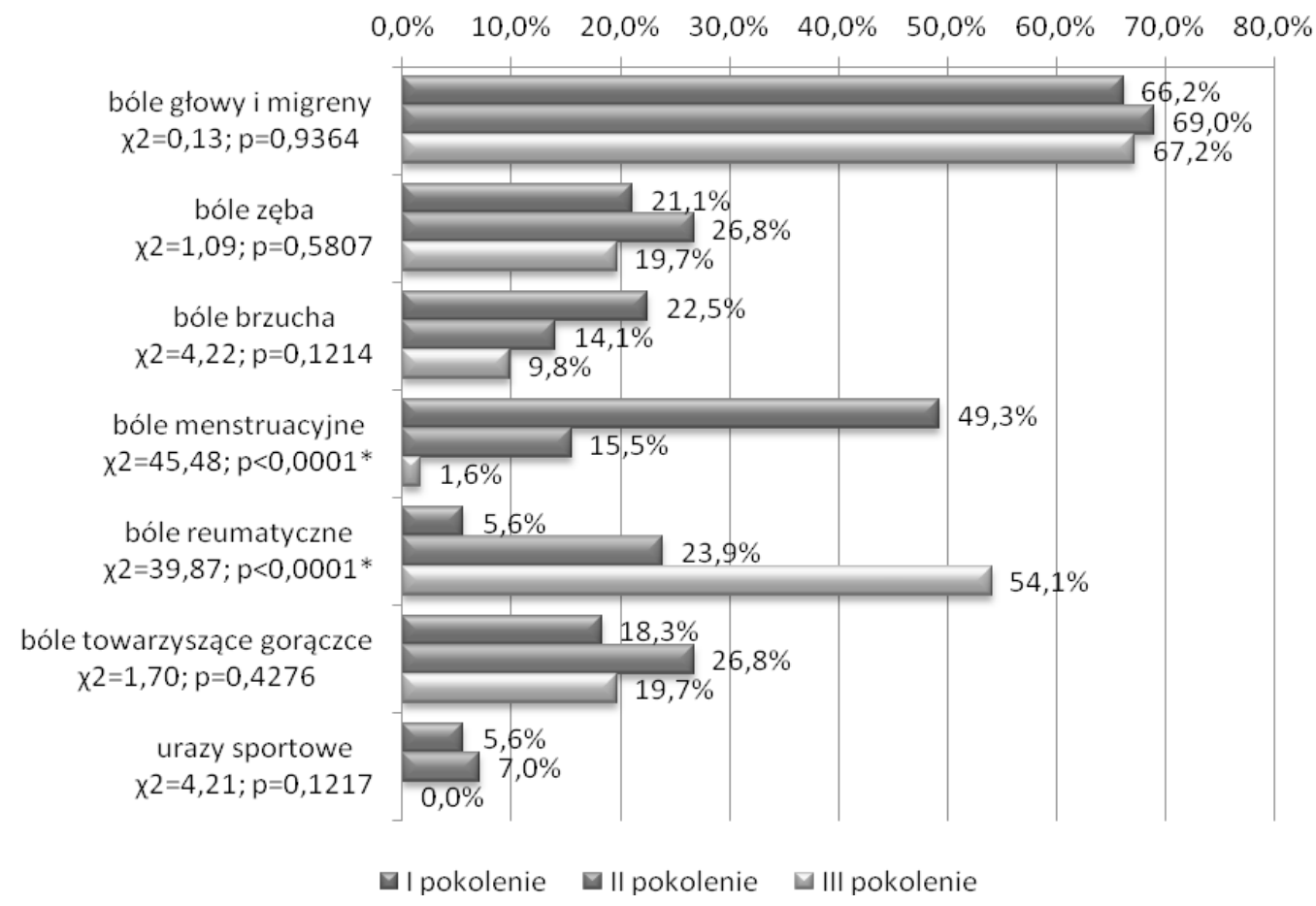

$\chi 2$-wartość testu Chi kwadrat Pearsona; *-istotne zróżnicowanie dla p<0,05

Rycina 3. Powody stosowania leków przeciwbólowych

Źródło: Opracowanie własne

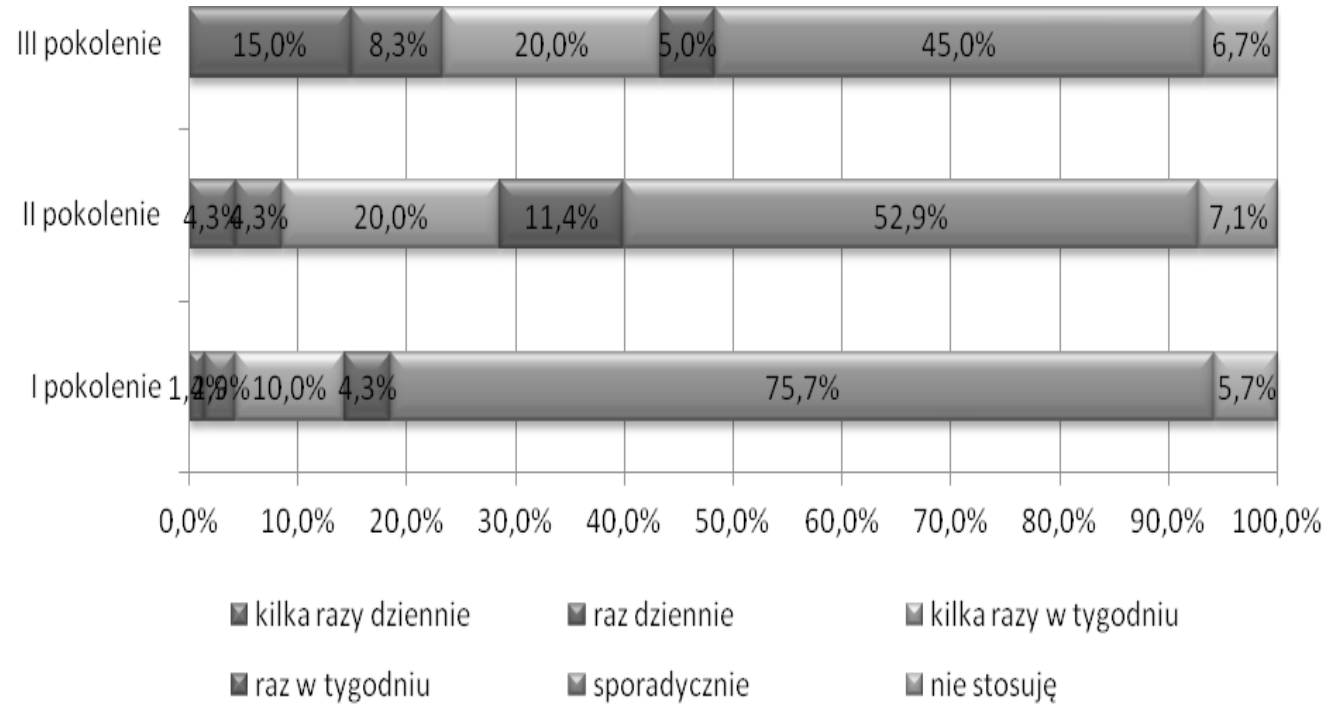

Wartość testu Chi kwadrat Pearsona: $\chi 2=23,72 ; p=0,0084^{*}$

$\chi 2$-wartość testu Chi kwadrat Pearsona; *-istotne zróżnicowanie dla $\mathrm{p}<0,05$

Rycina 4. Częstość stosowania leków przeciwbólowych przez osoby należące do trzech różnych pokoleń.

Źródło: Opracowanie własne

Stosowanie preparatów leczniczych bez konsultacji z lekarzem

Ponad 60\% ankietowanych (122 osoby) przyznaje się, iż w razie zaistniałej potrzeby, przyjmuje „na własną rękę" preparaty szeroko dostępne bez uprzedniej konsultacji z lekarzem bądź farmaceutą. Jako główne powody respondenci podają łatwość dostępu do farmaceutyków, długie kolejki w przy- chodni zdrowia oraz brak czasu na dokładną diagnostykę oraz wizyty u lekarzy. Dodatkowo, aż 29 osób $(14,29 \%)$ jest przeświadczonych o tym, że sami dobrze wiedzą co im dolega oraz w jaki sposób mogą sobie poradzić. Deklarowane przez ankietowanych powody leczenia się „na własną rękę” preparatami dostępnymi bez recepty zamieszczono na rycinie 6. 


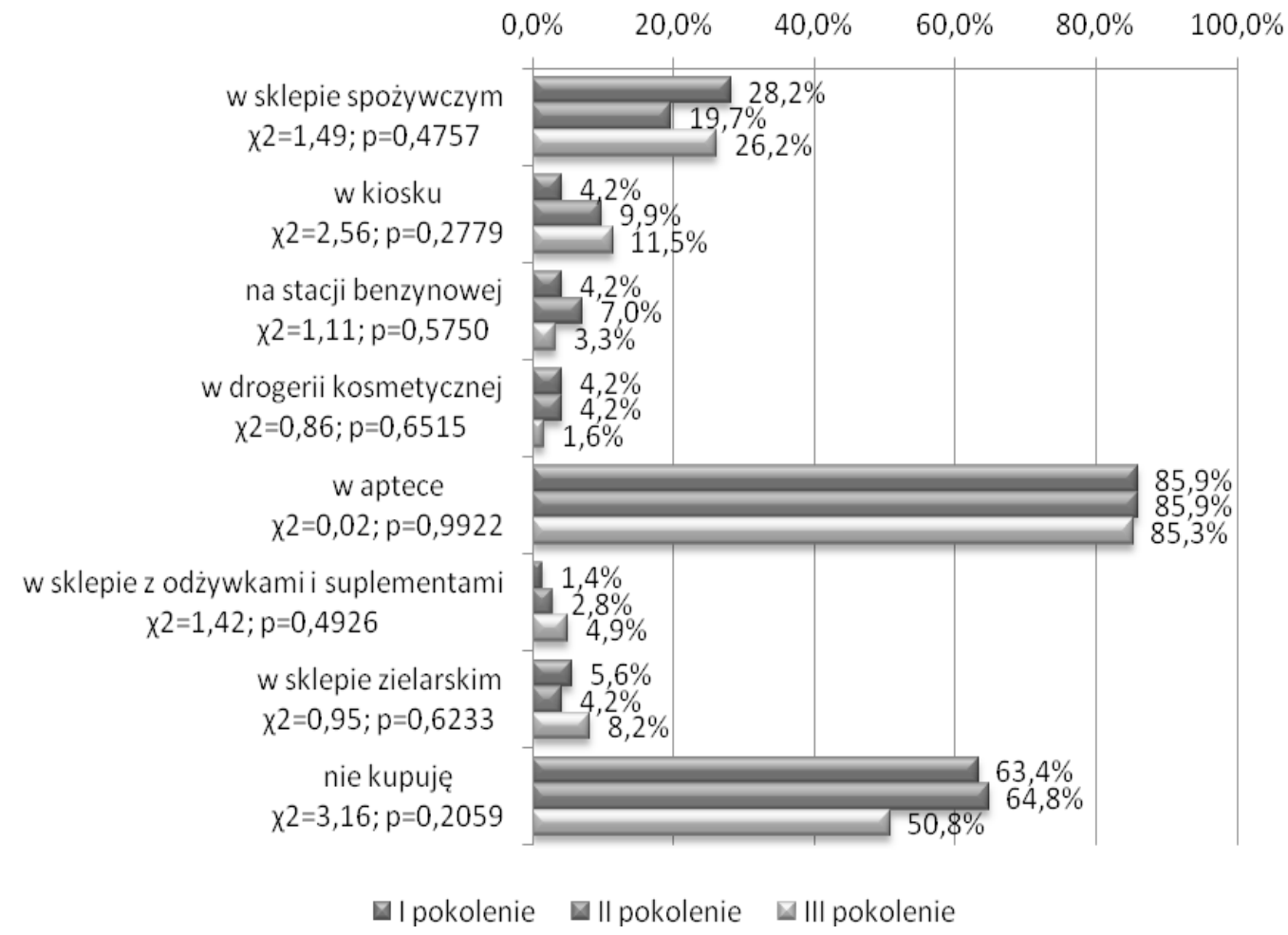

$\chi 2$-wartość testu Chi kwadrat Pearsona; *-istotne zróżnicowanie dla $\mathrm{p}<0,05$

Rycina 5. Miejsce zakupu leków przeciwbólowych

Źródło: Opracowanie własne

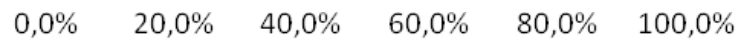

$$
\begin{aligned}
& x^{2}=7,50 ; p=0,0235^{*} \\
& \text { długie kolejki w przychodni } \\
& \chi 2=2,95 ; p=0,2293 \\
& x_{2}=1,48 ; p=0,4780 \\
& \chi 2=0,35 ; p=0,8401 \\
& \text { pomoże } \\
& x^{2}=2,09 ; p=0,3524 \\
& \text { IIpokolenie } \mathbf{\square} \text { II pokolenie } \square \text { III pokolenie }
\end{aligned}
$$

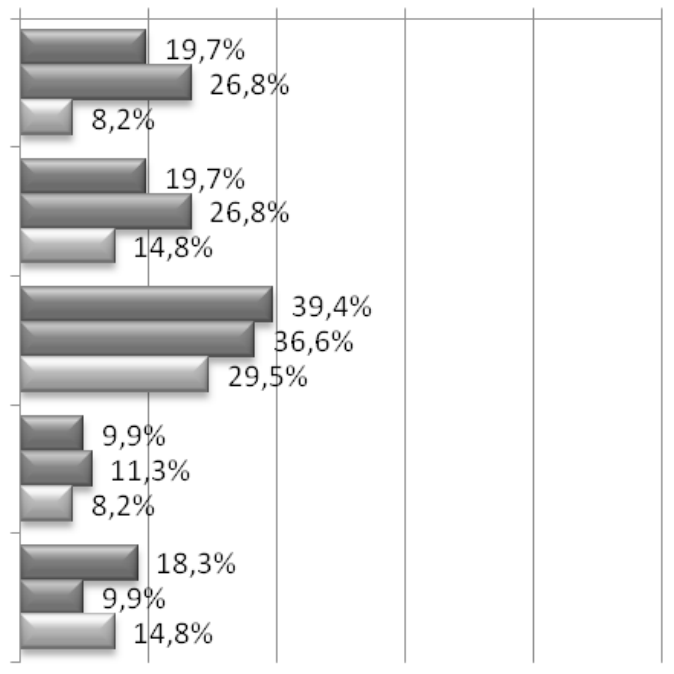

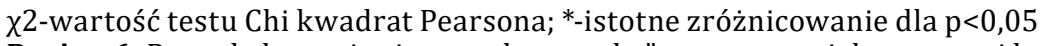

Rycina 6. Powody leczenia się „na własną rękę” preparatami dostępnymi bez recepty

Źródło: Opracowanie własne

\section{Dyskusja}

Z badań Szpringer i wsp. wykonanych na 277 dorosłych mieszkańcach województwa świętokrzyskiego, w tym 163 kobiety i 114 mężczyzn wynika, że leki dostępne bez recepty stosowane były kilka razy w roku przez $25,27 \%$ respondentów. Zdecydo- wana większość badanych zadeklarowała, że głównym miejscem zakupu leków dostępnych bez recepty jest apteka (55,60\%). Z przeprowadzonych przez autorów analiz wynika, że badani nie informują lekarzy o stosowanych lekach OTC i często stosują jednocześnie medykamenty zalecone przez lekarza $i$ te dostępne bez recepty (Springer i in., 2015). 
Z przeprowadzonych badań wynika, że osoby pokolenia III (dziadkowie) istotnie częściej deklarują występowanie chorób serca, nadciśnienia, cukrzycy, miażdżycy, schorzeń wątroby i schorzeń w obrębie układów moczowego i płciowego. Osoby młode częściej przyjmują leki przeciwbólowe podczas bólu menstruacyjnego, zaś osoby starsze z powodu bólów reumatycznych. Najczęściej wybieraną substancją czynną przeciwbólowych leków OTC jest ibuprofenum - częściej po takie preparaty sięgają osoby młode. Częstość stosowania leków przeciwbólowych różni się istotnie pomiędzy analizowanymi grupami respondentów należących do trzech różnych pokoleń. Sporadycznie po leki przeciwbólowe częściej sięgają osoby młode $(75,7 \%)$ niż osoby w wieku średnim $(52,9 \%)$ i osoby starsze (45\%).

Należy zauważyć, że środowisko farmaceutyczne popiera działania zmierzające do zakazu sprzedaży leków dostępnych bez recepty poza punktami aptecznymi kierując się dobrem pacjenta. Farmaceuci przypominają, iż w 1991 roku w sprzedaży pozaaptecznej można było kupić jedynie 11 produktów, w obecnej chwili jest to już ponad 3 tysiące preparatów. W pierwotnym założeniu szerszy dostęp do farmaceutyków miał być ułatwieniem dla klientów, a stał się zagrożeniem dla ich zdrowia.

Za przyczynę stosowania samoleczenia przeciwbólowego Bogusz i Majchrowska podają: dużą dostępność leków OTC $(66,1 \%)$, reklamę i jej przekaz (50\%), niechęć do kontaktu z lekarzem $(42,7 \%)$, porady znajomych $(32,3 \%)$, utrudniony dostęp do lekarza, kolejki $(25,8 \%)$, możliwość konsultacji $\mathrm{z}$ farmaceutą $(17,7 \%)$, łatwy dostęp do aptek $(16,9 \%)$, większą świadomość zdrowotną $(12,1 \%)$ oraz duży dostęp do informacji medycznych $(7,9 \%)$ (Bogusz, Majchrowska, 2008).

Z badań własnych wynika, że sugestie oraz pozytywne opinie ze strony celebrytów (znanej aktorki, aktora, sportowca występującego w reklamie) lub propozycja aktora odgrywającego rolę lekarza bądź farmaceuty wpływa na decyzję zakupową według 22 ankietowanych osób (10,84\%) - 6 osób $(8,45 \%)$ w pokoleniu I, 6 osób $(8,45 \%)$ w pokoleniu II oraz 10 osób (16,39\%) w pokoleniu III. Specjaliści od promocji za pomocą rozbudowanych narzędzi marketingowych i analiz rynku farmaceutycznego tak przygotowują kampanię reklamową, aby trafiła do jak najszerszej grupy odbiorców i przyniosła oczekiwany efekt w postaci znacznego wzrostu wpływów ze sprzedaży leku (Kondraszuk, 2011).
Co więcej, zastosowanie sformułowania „na wszelki wypadek" stwarza potrzebę zabezpieczenia się na wypadek nieprzewidzianych sytuacji, nagłego bólu czy zaopatrzenia się przed wyjazdem w miejsce, gdzie będzie utrudniony dostęp do apteki (Gardeła, Socała, 2003). Nie bez znaczenia pozostaje fakt, iż w reklamach środków przeciwbólowych dostępnych bez recepty występują osoby znane $\mathrm{z}$ ekranu lub osoby przypominające wyglądem personel związany ze służbą zdrowia np. lekarz, stomatolog, farmaceuta, fizjoterapeuta. W dalszym ciągu dominuje opinia, że najbardziej wiarygodnym źródłem reklamy środków farmaceutycznych pozostaje reklama telewizyjna wykorzystująca wizerunek znanej osoby, a nie opinia lekarza pierwszego kontaktu czy farmaceuty (Kondraszuk, 2003). Niewielu odbiorców reklam zdaje sobie sprawę, iż jest to statysta bądź aktor, który ma za zadanie odegrać rolę pracownika służby zdrowia. Kodeks Etyki Lekarskiej w art. 63 wyraźnie zabrania lekarzowi reklamowania czegokolwiek własnym nazwiskiem i wizerunkiem (Kodeks Etyki Lekarskiej, 2004). W badaniach własnych tylko 10,84\% ankietowanych przyznaje, iż rekomendacja osoby znanej bądź osoby podającej się za lekarza lub farmaceutę ma wpływ na zakup tego konkretnego preparatu. Brakuje powszechnej świadomości, że wszelkie problemy zdrowotne należy właściwie zdiagnozować i wybrać odpowiednie leczenie (Bogusz, Majchrowska, 2008)

\section{Podsumowanie}

Na przestrzeni 8 lat wzrosła blisko 2-krotnie sprzedaż apteczna leków OTC (z 3,859 mld zł do 7,335 mld zł) (Markiewicz, 2014). Częstość ich stosowania różni się pomiędzy analizowanymi grupami respondentów należących do trzech różnych pokoleń. Osoby starsze częściej (15\%) niż osoby młode $(1,4 \%)$ sięgają po leki przeciwbólowe kilka razy dziennie. Natomiast zdecydowanie wyższy odsetek osób młodego pokolenia $(75,7 \%)$ stosuje tego typu preparaty sporadycznie. Samoleczenie, zwłaszcza przeciwbólowe, odgrywa istotną rolę w codziennym życiu wielu Polaków. Wpływ na to ma szeroki dostęp do farmaceutyków, brak czasu na diagnostykę i zbyt długie kolejki do lekarza pierwszego kontaktu. Rynek farmaceutyczny z roku na rok poszerza oferty w zakresie różnego typu preparatów o działaniu przeciwbólowym, co w konsekwencji prowadzi do nadmiernego ich spożycia przez społeczeństwo.

\section{Literatura:}

1. Bogusz, R., Majchrowska, A. (2008). Uwarunkowania stosowania leków dostępnych bez recepty (OTC) w opinii studentów farmacji. W: R. Domżał-Drzewicka, A. Ścibior, H. Kaźmierak (red.), Uzależnienia a rodzina. Wybrane zagadnienia s. 201-204. Lublin: MAKmed.

2. Eisenberg, E., Marinangeli, F., Birkhahm, J., Paladín, A., Varrassi, G. (2005). Time to modify the WHO analgesic leader? Pain Clinical Updates, 13(5), 1-4.

3. Gardeła, A., Socała, D. J. (2003). Marketing leków bez recepty. Marketing w Praktyce, 5, 46-49. 
4. Jarosz, M., Respondek, W. (2011). Zażywanie suplementów u osób w wieku starszym. W: M. Jarosz Żywienie osób w wieku starszym. Porady lekarzy i dietetyków s. 99-118. Warszawa: PZWL.

5. Kodeks Etyki Lekarskiej z dnia 2 stycznia 2004 r. Biuletyn Naczelnej Rady Lekarskiej 1(81), XIV. Pobrane z: http://www.oil.org.pl/res/img/img/nil/gazeta/biuletyn/r2004/1_2004.pdf, [dostęp 19.11.2017].

6. Kondraszuk, A. (2011). Wpływ reklamy suplementów diety na decyzje zakupowe konsumentów W: Contemporary Public Health Issues, (103-112). Biała Podlaska: Państwowa Szkoła Wyższa im. Papieża Jana Pawła II w Białej Podlaskiej.

7. Markiewicz, M. (2014). Rynek suplementów potrzebuje uregulowania. Puls Farmacji, 4(84), 1-4.

8. Rajtar-Cynke, G. (red.). (2012). Farmakologia (73-78). Warszawa: PZWL.

9. Szpringer, M., Olędzka, M., Kosecka, J., Galińska, E. M., Chmielewski, J., Wawrzeńczyk, M., Sobczyk, B., Wawrzeńczyk, M. (2015). Stosowanie leków dostępnych bez recepty i suplementów diety przez osoby dorosłe z województwa świętokrzyskiego. Medycyna Ogólna i Nauki o Zdrowiu, 21(2), 163-167. https:// doi.org/10.5604/20834543.1152914

10. Ustawa z dnia 6 września 2001 r. o prawie farmaceutycznym (Dz.U. 2001 Nr 126 poz. 1381 z późn. zm.). Pobrane z: http://prawo.sejm.gov.pl/isap.nsf/DocDetails.xsp?id=wdu20011261381 [dostęp 18.04.2018].

11. Woroń, J., Filipczak-Bryniarska, I., Wordliczek, J. (2001). Leki złożone w farmakologii bólu. Paracetamol i tramadol. Geriatria, 1, 30-33.

12. Wykowski, J. (2016). Żeby medycyna nam nie zaszkodziła, czyli o nadużywaniu leków i nie tylko. Pobrane z: http://www.rynekzdrowia.pl/Uslugi-medyczne/Zeby-medycyna-nam-nie-zaszkodzila-czyli-onaduzywaniu-lekow-i-nie-tylko,160043,8.html, [dostęp 19.11.2017] 